\title{
Pentraksyna 3 jako niezależny marker rozwoju choroby wieńcowej, stopnia jej zaawansowania oraz rokowania
}

\section{Pentraxin 3 as an independent marker of coronary artery disease development, progression and prognosis}

\author{
Monika Gil, Anna Lisowska, Włodzimierz J. Musiał, Małgorzata Knapp \\ Klinika Kardiologii Uniwersytetu Medycznego w Białymstoku
}

\section{Streszczenie}

Pentraksyna 3 (PTX3) jest białkiem ostrej fazy i, podobnie jak białko C-reaktywne, należy do nadrodziny pentraksyn. Jest produkowana pod wpływem czynników zapalnych przez różnego rodzaju komórki, między innymi związane bezpośrednio z rozwojem miażdżycy, na przykład komórki śródbłonka naczyniowego czy makrofagi, w związku z czym PTX3 postrzega się jako specyficzny marker lokalnego zapalenia. Jest białkiem odzwierciedlającym proces zapalny w chorobach układu sercowo-naczyniowego, włączając bezobjawową miażdżyce, stabilną chorobę wieńcową, ostre zespoły wieńcowe (ACS) i niewydolność serca. Związek PTX3 z czynnikami ryzyka sercowo-naczyniowego pozwala sądzić, że jest ona obiecującym parametrem oceny rozwoju miażdżycy. Dotychczasowe badania sugerują, że może być ona przydatnym markerem w diagnostyce ACS. Co ważne, u pacjentów po już przebytym incydencie wieńcowym czy też u chorych z niewydolnością serca PTX3 okazała się niezależnym czynnikiem niekorzystnego rokowania.

Słowa kluczowe: pentraksyna 3, miażdżyca, blaszki miażdżycowe, czynniki ryzyka sercowo-naczyniowego, ostry zespół wieńcowy, niewydolność serca

Folia Cardiologica 2017; 12, 1: 55-60

\section{Wstęp}

Znaczącą rolę w powstawaniu, progresji i erozji blaszek miażdżycowych odgrywa proces zapalny ścian naczyń krwionośnych. Skutkiem jest niedokrwienie mięśnia sercowego. Dlatego badacze są szczególnie zainteresowani poszukiwaniem biomarkerów, które służyłyby wczesnemu wykrywaniu i monitorowaniu procesu zapalenia. Przydatność kliniczna większości znanych biomarkerów zapalenia jest ograniczona niską swoistością w odniesieniu do patologii sercowo-naczyniowych. Pentraksyna 3 (PTX3, pentraxin 3) podobnie jak białko C-reaktywne
(CRP, C-reactive protein) jest białkiem ostrej fazy, należącym do nadrodziny pentraksyn. Jest produkowana pod wpływem czynników zapalnych przez różnego rodzaju komórki, między innymi związane bezpośrednio z rozwojem miażdżycy komórki śródbłonka naczyń, mięśni gładkich czy makrofagi [1, 2]. W związku z tym PTX3 wyłoniła się jako specyficzny marker lokalnego zapalenia. W ostatnich kilkunastu latach badacze próbowali określić jej związek z uznanymi czynnikami ryzyka sercowo-naczyniowego oraz przydatność w diagnostyce, monitorowaniu i rokowaniu w ostrych zespołach wieńcowych (ACS, acute coronary syndrome). 


\section{Pentraksyna 3}

Rodzina pentraksyn jest grupą białek ostrej fazy o budowie pentamerycznej i zależnie od długości łańcucha dzieli się na pentraksyny krótkie (CRP i surowiczy amyloid P [SAP, serum amyloid P]) oraz długie (m.in. PTX3 i PTX4) [1]. Jako pierwszy PTX3 zidentyfikował i opisał w 1992 roku Breviaro w komórkach śródbłonka naczyniowego i fibroblastach. Jest to białko składające się z 381 aminokwasów o masie 40,165 Da [1, 2]. W odróżnieniu od krótkich pentraksyn, które są produkowane w wątrobie, PTX3 jest wytwarzana i uwalniana lokalnie przez kilka rodzajów komórek, w szczególności monocyty/makrofagi, komórki dendrytyczne, chondrocyty, fibroblasty, komórki śródbłonka naczyniowego, mięśni gładkich, adipocyty, komórki nabłonkowe nerek, pneumocyty [3, 4]. Poza pulą pentraksyny produkowanej w odpowiedzi na mediatory zapalne istnieje także stała pula PTX3 gromadzona w ziarnistościach neutrofilów i uwalniana do przestrzeni zewnątrzkomórkowej w ostrej fazie zapalenia [5]. Produkcja PTX3 jest odpowiedzią na mediatory stanu zapalnego, głównie interleukinę $1 \beta$ (IL-1 $\beta$ ) czynnik martwicy nowotworów $\alpha$ (TNF- $\alpha$, tumor necrosis factor $\alpha$ ), utlenione cząsteczki lipoprotein i niskiej gęstości (ox-LDL, oxidized low-density lipoprotein) [6, 7]. Czynnikami, które hamuja produkcję PTX3, są: interferon $y$ (IFN-y), interleukina 4 (IL-4), interleukina 13 (IL-13), $1 \alpha$-25-dihydroksywitamina D3, prostaglandyna E2 (PGE2) [8]. Ponadto PTX3 pełni rolę regulatora w zapaleniu. W stanie masywnej aktywacji leukocytów uwalniana lokalnie tłumi ich aktywację.

Stężenie PTX3 jako białka ostrej fazy w warunkach fizjologicznych jest niskie i wynosi poniżej $2 \mathrm{ng} / \mathrm{ml}$ w organizmie ludzkim; szybko wzrasta (maksymalne stężenie osiąga w ciągu 6-8 h) w takich stanach chorobowych, jak: sepsa, ostre stany zapalne bakteryjne, grzybicze, zaostrzenie niewydolności krążenia, ostre zespoły wieńcowe, niektóre choroby nowotworowe i choroby autoimmunologiczne. Stężenie PTX3 koreluje z ciężkością choroby; maksymalne stężenia w organizmie ludzkim to $200-800 \mathrm{ng} / \mathrm{ml}[8,9]$. W ACS stężenie PTX3 osiąga swój szczyt po około 7,5 h i powraca do wartości wyjściowej w ciągu 3 dni [8].

\section{Pentrasyna 3 a czynniki ryzyka \\ sercowo-naczyniowego}

Pomiar grubości kompleksu intima-media (IMT) pozwala oszacować stopień zaawansowania miażdżycy w organizmie i przewidywać wystąpienie zdarzeń sercowo-naczyniowych. Potwierdzenie związku PTX3 z tym czynnikiem ryzyka pozwalałoby wykorzystać jej oznaczanie w diagnostyce chorób układu sercowo-naczyniowego w fazie subklinicznej. Dotychczasowe prace wskazują jednak, że stężenia PTX3 korelują z IMT jedynie u osób z zaawansowaną miażdżycą. Nie wykazano takiej zależności u osób bez chorób układu sercowo-naczyniowego lub we wczesnych jej stadiach [10-12]. W badaniu z zastosowaniem pitawastatyny u pacjentów z nie- leczoną hipercholesterolemią i wyjściowo podwyższonym stężeniem PTX3 zaobserwowano, że podawanie tej statyny nie tylko poprawiło profil lipidowy, ale również spowodowało zmniejszenie grubości IMT i obniżenie stężenia PTX3 [13]. Zależność ta zachęca do dalszych badań, w których PTX3 może się wyłonić jako użyteczny parametr w wykrywaniu i monitorowaniu pacjentów z asymptomatyczną miażdżycą.

Zaburzenia gospodarki lipidowej pod postacią wysokich stężeń cholesterolu całkowitego, LDL, triglicerydów, niskich stężeń cholesterolu frakcji HDL (high-density lipoprotein) są uznanym czynnikiem ryzyka chorób układu sercowo-naczyniowego. W ogólnej populacji osób zdrowych nie obserwuje się związku PTX3 z profilem lipidowym [14]. Koreluje ona natomiast dodatnio ze stężeniami cholesterolu frakcji LDL i triglicerydów u osób z zaburzeniami gospodarki węglowodanowej, insulinoopornością, zespołem metabolicznym i cukrzycą typu 2 [15-17].

Cukrzyca zwiększa ryzyko chorób układu sercowo-naczyniowego 2-3-krotnie. U pacjentów z cukrzycą zaobserwowano wyższe stężenia PTX 3 niż u pacjentów bez tej choroby $[11,18,19]$. Stwierdzono liniową zależność między PTX3 a ciężkością zmian miażdżycowych w koronarografii. Poza tym PTX3 okazała się bardziej czułym i specyficznym markerem wykrywania choroby niedokrwiennej serca u pacjentów z cukrzycą typu 2 niż CRP o wysokiej czułości (hsCRP, high-sensitivity CRP) [17].

Otyłość w wielu krajach uprzemysłowionych stała się jednym z najważniejszych czynników ryzyka chorób układu sercowo-naczyniowego. W dużych, populacyjnych badaniach nie zaobserwowano związku PTX 3 z otyłością [11, 18, 20]. Natomiast w zespole metabolicznym wykazano, że stężenie PTX3 koreluje ujemnie z masą ciała, wskaźnikiem masy ciała (BMI, body mass index), obwodem talii, stężeniem glukozy w surowicy krwi, stężeniem interleukiny 6 (IL-6) w osoczu i dodatnio z wartościami cholesterolu frakcji HDL i adiponektyny [21]. U otyłych osób z ACS stwierdza się niższe wartości PTX3 niż u badanych z prawidłową masą ciała. Stężenie PTX3 jest również niższe u osób z ACS i większym obwodem talii. Biorąc pod uwage wyniki dotychczas przeprowadzonych badań, w których PTX3 ujawniła się jako niekorzystny czynnik rokowniczy u pacjentów z ACS, można wywnioskować, że niższe stężenia PTX3 u otyłych pacjentów są predyktorem lepszego rokowania i przeżycia [22].

W przeprowadzonych dotychczas badaniach wykazano liniową zależność między wartościami ciśnienia tętniczego a stężeniem PTX3 $[11,17]$. Innym uznanym, modyfikowalnym, czynnikiem ryzyka sercowo-naczyniowego jest palenie tytoniu. W dotychczasowych doniesieniach nie stwierdzono związku stężenia PTX3 z paleniem papierosów, natomiast u osób spożywających alkohol stężenia PTX3 były wyższe $[11,14]$. Poza tym w dużych populacyjnych badaniach wykazano, że stężenie PTX3 zwiększało się z wiekiem, przy czym u mężczyzn zaobserwowano wyższe stężenia niż u kobiet [11, 14, 18, 20, 23]. 


\section{Pentraksyna 3 a blaszki miażdżycowe}

Ekspresję PTX3 wykryto w blaszkach miażdżycowych, głównie makrofagach i neutrofilach, co sugeruje, że wartości PTX3 mogą odzwierciedlać stopień ich zaawansowania. Blaszki pokryte cienkim włóknistym płaszczem częściej ulegają pęknięciu z wytworzeniem skrzepu. W badaniach dowiedziono, że stężenie PTX3 jest odwrotnie proporcjonalne do grubości płaszcza włóknistego [10]. Wysokie stężenia PTX3 (> 3,24 ng/ml) mogą być silnym predyktorem niestabilnej blaszki miażdżycowej nawet u pacjentów ze stabilną chorobą wieńcową [24]. Dlatego oznaczenie stężenia PTX3 w codziennej praktyce klinicznej pozwoliłoby wyłonić chorych szczególnie zagrożonych wystąpieniem ostrego zespołu wieńcowego.

Wysokie stężenia osoczowej PTX3 mogą odzwierciedlać stopień zaawansowania zmian miażdżycowych w naczyniach wieńcowych. Stężenia PTX3 i hsCRP u osób bez istotnego zwężenia w naczyniu wieńcowym $(<50 \%)$ są niższe niż u osób ze zwężeniem przekraczającym $50 \%$ w jednym lub większej liczbie naczyń wieńcowych. Połączenie czynników, tj. stężeń hsCRP i PTX3 oraz profilu lipidowego, silniej koreluje z obecnością wielonaczyniowej choroby wieńcowej niż każdy z tych markerów osobno $[25,26]$. Wyraźny związek stężenia PTX3 z rozległością zwężeń miażdżycowych zaobserwowano również u pacjentów z niewydolnością nerek. Zależności takiej nie udowodniono w odniesieniu do CRP, co sugeruje, że PTX3 może być lepszym czynnikiem predykcyjnym progresji zmian miażdżycowych w naczyniach wieńcowych u pacjentów z niewydolnością nerek niż CRP. Teza ta wymaga jednak potwierdzenia w kolejnych badaniach [26].

Aterogenna lipoproteina LDL wpływa na zwiększone uwalnianie PTX3 w mięśniach gładkich [27]. Jest ona także obecna w zaktywowanych neutrofilach, które odgrywają znaczącą rolę w początkowej fazie tworzenia blaszek miażdżycowych oraz ich progresji. W badaniach na myszach pozbawionych genu kodującego PTX3 i apoproteinę E zaobserwowano zwiększoną ekspresję genów dla czynników prozaplanych w ścianach naczyń: czynników adhezyjnych (cząsteczek adhezji międzykomórkowej 1 [ICAM-1, intracellular adhesion molecule 1], cząsteczek adhezji śródbłonka naczyniowego 1 [VCAM-1, vascular cell adhesion molecule 1], E-selektyny), cytokin (IL-4, IL-6, TNF- $\alpha$ ), chemokin. $U$ myszy tych obserwowano rozległe zmiany miażdżycowe w naczyniach wieńcowych oraz zwiększoną akumulację makrofagów w blaszkach miażdżycowych [28].

Oprócz opisywanej proaterogennej roli PTX3 badacze zaobserwowali, że może ona również działać przeciwmiażdżycowo. Ochronna rola PTX3 w aterogenezie może być realizowana przez wiązanie i inaktywację naczyniowego czynnika wzrostu fibroblastów 2 (FGF-2, fibroblastic growth factor 2) odpowiedzialnego za proliferację mięśni gładkich, co jest jednym z patomechanizmów miażdżycy. Dlatego podwyższone stężenia PTX3 mogą odgrywać również rolę ochronną w uszkodzeniu naczynia, tak jak leukocyty w okresie infekcji
[29]. Płytki krwi są składnikiem zakrzepu zamykającego naczynie wieńcowe po pęknięciu niestabilnej blaszki miażdżycowej, co powoduje niedokrwienie mięśnia sercowego. W badaniach wykazano, że PTX3 uwalniana ze zaktywowanych neutrofilów pod wpływem mediatorów stanu zapalnego w reakcji na uszkodzenie, na przykład niedokrwienie, wiąże się z płytkami krwi, uniemożliwiając w ten sposób tworzenie się agregatów płytkowych, które osłabiają przepływ krwi w mikrokrążeniu [30]. Udowodniono, że PTX3 koreluje odwrotnie proporcjonalnie z markerami aktywacji płytek, między innymi 11-dehydro-tromboksanem $B_{2}$, co może świadczyć o tym, że PTX3 cechują właściwości przeciwpłytkowe, przez co może chronić przed niedokrwieniem [31].

\section{Pentraksyna 3 w diagnostyce} ostrych zespołów wieńcowych Jednym ze źródeł krążącej PTX3 jest uszkodzona, pęknięta blaszka miażdżycowa, co stało się przyczyną zainteresowania badaczy w wykorzystywaniu PTX3 w diagnostykce ACS. Podwyższone stężenie PTX 3 jest wykrywalne znacznie wcześniej niż stężenie CRP, które osiąga maksimum po $48 \mathrm{~h}$. Maksymalne stężenie PTX3 obserwuje się po około $6 \mathrm{~h}$ od początku bólu w klatce piersiowej. Indywidualne stężenie PTX3 w ACS obserwowano niezależnie od rozległości martwicy mięśnia sercowego czy niewydolności serca ocenianej według klasy Killipa [8].

Aby ocenić przydatność PTX3 w diagnostyce ACS porównywano jej stężenia z wartościami znanych biomarkerów uszkodzenia mięśnia sercowego, tj. troponiny T (TnT), troponiny I (TnI), ludzkiego białka wiążącego kwasy tłuszczowe (H-FABP, human fatty acid-binding protein), hsCRP. Wykazano wyższe czułość i swoistość PTX3 niż TnT oraz H-FABP we wczesnej fazie ACS [32]. W dotychczas przeprowadzonych populacyjnych badaniach, między innymi MESA (Multi-Ethnic Study of Atherosclerosis), CORONA (Controlled Rosuvastatin Multinational Trial in Heart Failure) i GISSI-HF (Gruppo Italiano di Studio della Sopravvivenza nella Insufficienza cardiaca-Heart Failure), dowiedziono również, że funkcja nerek nie wpływa na wartości PTX3, co może dawać jej przewagę nad innymi markerami, tj. troponina czy białkiem natriuretycznym typu B (BNP, B-type natriuretic poptide), których stężenia silnie zależą od wydolności tego narządu [18, 33].

\section{Pentraksyna 3 jako czynnik prognostyczny w chorobie wieńcowej}

U pacjentów ze stabilną chorobą wieńcową wyższe stężenia PTX3 są związane ze zwiększonym ryzykiem zdarzenia sercowo-naczyniowego - zawału serca, udaru mózgu, zgonu z przyczyn sercowo-naczyniowych, incydentu zaostrzenia niewydolności serca - oraz zwiększoną śmiertelnością całkowitą [20]. Po zawale serca z uniesieniem odcinka ST (STEMI, ST-elevation myocardial infarction) leczonym przezskórną interwencją wieńcową $(\mathrm{PCl}$, percutaneous 
coronary intervention) wysokie stężenia PTX3 przed PCl wiążą się z nieprawidłową perfuzją mięśnia sercowego po zabiegu, co jest uznanym czynnikiem niekorzystnego rokowania u pacjentów z ACS. W 9-miesięcznej obserwacji pacjenci z wyższymi stężeniami PTX3 przed PCl i nieprawidłową perfuzją po zabiegu (0-1 w skali MBG [Myocardial Blush Grade]) istotnie częściej doznawali niekorzystnych zdarzeń sercowo-naczyniowych [34]. Wyższe wyjściowo stężenie PTX3 wiąże się z częstszym występowaniem powtórnych incydentów sercowo-naczyniowych. Wartość PTX3 koreluje ze stężeniami hsCRP, Tnl i N-końcowego propeptydu natriuretycznego typu B (NT-proBNP, N-terminal pro-B-type natriuretic peptide). Wykazano, że PTX3 jest niezależnym predyktorem wewnątrzszpitalnej i 30-dniowej śmiertelności u osób z zawałem serca bez uniesienia odcinka ST (NSTEMI, non-ST-elevation myocardial infarction) [35]. Również w obserwacji 6-miesięcznej, w grupie pacjentów z niestabilną dławicą piersiową i NSTEMI, PTX3 i NT-proBNP ujawniły się jako niezależne czynniki zdarzenia sercowego [36]. Stwierdzono ponadto, że PTX3 u pacjentów po ACS ma większe znaczenie prognostyczne niż CRP, kinaza kreatynowa (CK, creatine kinase), TnT i NT-proBNP w ocenie 3-miesięcznej śmiertelności [9]. Jednak w 5-letniej obserwacji populacji pacjentów z badania CARE (Cholesterol and Recurrent Events), obejmującego 4159 pacjentów po przebytym zawale serca, nie potwierdzono roli PTX3 jako markera zdarzeń sercowo-naczyniowych [37].

Potrzebne są dalsze badania w dużej populacji pacjentów, w których zostanie oceniona przydatność kliniczna PTX3 w ACS. Seryjne oznaczenia PTX3 mogą być użyteczne w odzwierciedlaniu lokalnego stanu zapalnego oraz szacowania ryzyka ponownego zdarzenia wieńcowego, co pozwoliłoby na identyfikację pacjentów z grupy szczególnie wysokiego ryzyka sercowo-naczyniowego i optymalizację terapii.

\section{Pentraksyna 3 a niewydolność serca}

Niewydolność serca jest jednym z rosnących problemów współczesnej kardiologii. Mimo znacznego postępu w tej dziedzinie medycyny rokowanie u pacjentów z niewydolnością serca pozostaje poważne. W tej grupie chorych stwierdza się znacząco podwyższone stężenie PTX3. Koreluje to ze stopniem zaawansowania choroby [38]. Pentraksyna 3 może być również czynnikiem prognostycznym u pacjentów z niewydolnością serca. Wyniki badań CORONA i GISSI-HF wskazały, że podwyższone stężenia PTX3 były związane z wiekiem i stopniem zaawansowania niewydolności krążenia określanej według klasy New York Heart Association (NYHA). Najwyższe stężenia PTX3 obserwowano u chorych z niewydolnością o etiologii niedokrwiennej. Wyjściowo podwyższone stężenia PTX3 okazały się także niezależnym czynnikiem prognostycznym hospitalizacji z powodu zaostrzenia objawów niewydolności krążenia, zgonu z przyczyn sercowo-naczyniowych oraz całkowitej śmiertelności, a zmiany w stężeniu PTX3 w 3-miesięcznym okresie obserwacji były niezależnym czynnikiem prognostycznym śmiertelności [34]. W grupie chorych ze STEMI leczonych pierwotną PCI (pPCl, primary PCl) PTX3 jest niezależnym markerem rozwoju niewydolności lewej komory oraz śmiertelności 30-dniowej i rocznej. Wartość prognostyczna PTX3 okazuje się porównywalna z wartością prognostyczną obecnie używanych skal, tj. TIMI (Thrombolysis In Myocardial Infarction), GRACE (GRACE Risk Score), czy stężenia BNP [23]. Istnieje silna zależność między stężeniem PTX3 oznaczonym 24 godziny od początku hospitalizacji a punktacją w skali GRACE stosowanymi jako markery w określaniu ryzyka zgonu z przyczyn sercowych oraz jakiejkolwiek przyczyny w obserwacji wewnątrzszpitalnej i 6-miesięcznej [39].

Pentraksyna 3 jest również przydatnym markerem w szacowaniu ryzyka zdarzeń sercowo-naczyniowych u pacjentów z niewydolnością serca z zachowaną funkcją skurczową lewej komory. U chorych z wyższą wartością PTX3 znacząco częściej dochodzi do niekorzystnych incydentów sercowo-naczyniowych. Częstość występowania niekorzystnych zdarzeń sercowo-naczyniowych silniej koreluje z podwyższoną wartością PTX3 niż z dotychczas stosowanymi markerami - stężeniami BNP i hsCRP [40].

\section{Podsumowanie}

Pentraksyna 3 jest białkiem ostrej fazy odzwierciedlającym proces zapalny w chorobach układu sercowo-naczyniowego, włączając bezobjawową miażdżycę, stabilną chorobę wieńcową, ostre zespoły wieńcowe i niewydolność serca. Gwałtowny wzrost jej osoczowego stężenia wskutek uwalniania przez różnego rodzaju komórki podczas m.in. ostrego zespołu wieńcowego potwierdza, że może ona być wczesnym markerem odpowiedzi zapalnej w chorobach sercowo-naczyniowych, wykorzystywanym w diagnostyce zawału mięśnia sercowego. Jej przewaga nad innymi markerami stanu zapalnego, tj. CRP, fibrynogenem polega na jej pozawątrobowej produkcji, niezależnej od wydolności tego organu, dzięki czemu precyzyjnie odzwierciedla nasilenie miejscowego stanu zapalnego. Związek PTX3 z czynnikami ryzyka sercowo-naczyniowego pozwala sądzić, że może być ona obiecującym markerem oceny rozwoju miażdżycy subklinicznej i pełnoobjawowej, który pozwoli na wcześniejsze wyodrębnienie osób z grupy wysokiego ryzyka rozwoju chorób układu sercowo-naczyniowego. Co ważne u pacjentów po już przebytym incydencie wieńcowym, czy też u chorych z niewydolnością serca PTX3 okazała się być niezależnym czynnikiem niekorzystnego rokowania. Analizując dostępne badania PTX3 wydaje się atrakcyjnym celem w profilaktyce i terapii chorób sercowo-naczyniowych. Trafność tej hipotezy mogą rozstrzygnąć przyszłe badania kliniczne.

\section{Konflikt interesów}

Autorzy deklarują brak konfliktu interesów. 


\section{Abstract}

Pentraxin 3 (PTX3) is an acute phase protein that, likely to C-reactive protein (CRP), belongs to pentraxin superfamily. PTX3 is produced as a response to inflammatory mediators by several types of cells directly associated with atherosclerosis such as endothelial cells or macrophages. Thus PTX3 appears to be a specific indicator of localized inflammatory process. PTX3 reflects inflammatory status in cardiovascular diseases such as subclinical atherosclerosis, coronary artery disease, acute coronary syndromes (ACS) and heart failure. Association of PTX3 with cardiovascular risk factors suggests that it can be a promising marker of subclinical and symptomatic atherosclerosis. Previous research suggests that PTX3 may be a useful diagnostic marker of ACS. Furthermore, in patients after ACS or with heart failure it appears an independent prognostic factor.

Key words: pentraxin 3, atherosclerosis, atherosclerotic plaque, cardiovascular risk factors, coronary artery disease, acute coronary syndromes, heart failure

Folia Cardiologica 2017; 12, 1: 55-60

\section{Piśmiennictwo}

1. Mantovani A, Garlanda C, Bottazzi B, et al. The long pentraxin PTX3 in vascular pathology. Vascul Pharmacol. 2006; 45(5): 326-330, doi: 10.1016/j.vph.2006.08.011, indexed in Pubmed: 17023219.

2. Breviario F, d'Aniello EM, Golay J, et al. Interleukin-1-inducible genes in endothelial cells. Cloning of a new gene related to C-reactive protein and serum amyloid P component. J Biol Chem. 1992; 267(31): 22190-22197, indexed in Pubmed: 1429570.

3. Han B, Mura M, Andrade CF, et al. TNFalpha-induced long pentraxin PTX3 expression in human lung epithelial cells via JNK. J Immunol. 2005; 175(12): 8303-8311, indexed in Pubmed: 16339571.

4. Introna M, Alles V, Castellamo M, et al. Cloning of mouse extrahepatic sites. Blood. 1996; 87(5): 1862-1872, indexed in Pubmed: 8634434.

5. Jaillon S, Peri G, Delneste $Y$, et al. The humoral pattern recognition receptor PTX3 is stored in neutrophil granules and localizes in extracellular traps. J Exp Med. 2007; 204(4): 793-804, doi: 10.1084/ /jem.20061301, indexed in Pubmed: 17389238.

6. Garlanda C, Hirsch E, Bozza S, et al. Non-redundant role of the long pentraxin PTX3 in anti-fungal innate immune response. Nature. 2002; 420(6912): 182-186, doi: 10.1038/nature01195, indexed in Pubmed: 12432394 .

7. Nauta AJ, Bottazzi B, Mantovani A, et al. Biochemical and functional characterization of the interaction between pentraxin 3 and $\mathrm{C} 1 \mathrm{q}$. Eur J Immunol. 2003; 33(2): 465-473, doi: 10.1002/immu.200310022, indexed in Pubmed: 12645945.

8. Peri G, Introna M, Corradi D, et al. PTX3, a prototypical long pentraxin, is an early indicator of acute myocardial infarction in humans. Circulation. 2000; 102(6): 636-641, doi: 10.1161/01.cir.102.6.636.

9. Latini R, Maggioni AP, Peri G, et al. Lipid Assessment Trial Italian Network (LATIN) Investigators. Prognostic significance of the long pentraxin PTX3 in acute myocardial infarction. Circulation. 2004; 110(16): 2349-2354, doi: 10.1161/01.CIR.0000145167.30987.2E, indexed in Pubmed: 15477419.

10. Tazaki R, Tanigawa J, Fujisaka T, et al. Plasma pentraxin 3 level is associated with plaque vulnerability assessed by optical coherence tomography in patients with coronary artery disease. Int Heart J. 2016; 57(1): 18-24, doi: 10.1536/inj.15-248, indexed in Pubmed: 26673442.

11. Jenny NS, Arnold AM, Kuller LH, et al. Associations of pentraxin 3 with cardiovascular disease and all-cause death: the Cardiovascular
Health Study. Arterioscler Thromb Vasc Biol. 2009; 29(4): 594-599, doi: 10.1161/ATVBAHA.108.178947, indexed in Pubmed: 19164811.

12. Yano $\mathrm{Y}$, Matsuda S, Hatakeyama $\mathrm{K}$, et al. Plasma pentraxin 3 , but not high-sensitivity C-reactive protein, is a useful inflammatory biomarker for predicting cognitive impairment in elderly hypertensive patients. J Gerontol A Biol Sci Med Sci. 2010; 65(5): 547-552, doi: 10.1093/ /gerona/glq030, indexed in Pubmed: 20203097.

13. Ohbayashi H, Miyazawa C, Miyamoto K, et al. Pitavastatin improves plasma pentraxin 3 and arterial stiffness in atherosclerotic patients with hypercholesterolemia. J Atheroscler Thromb. 2009; 16(4): 490-500, indexed in Pubmed: 19729861.

14. Jylhävä J, Haarala A, Kähönen M, et al. Pentraxin 3 (PTX3) is associated with cardiovascular risk factors: the Health 2000 Survey. Clin Exp Immunol. 2011; 164(2): 211-217, doi: 10.1111/j.13652249.2011.04354.x, indexed in Pubmed: 21391986.

15. Zanetti M, Bosutti A, Ferreira C, et al. Circulating pentraxin 3 levels are higher in metabolic syndrome with subclinical atherosclerosis: evidence for association with atherogenic lipid profile. Clin Exp Med. 2009; 9(3): 243-248, doi: 10.1007/s10238-009-0039-z, indexed in Pubmed: 19238513.

16. Yamasaki K, Kurimura M, Kasai T, et al. Determination of physiological plasma pentraxin 3 (PTX3) levels in healthy populations. Clin Chem Lab Med. 2009; 47(4): 471-477, doi: 10.1515/CCLM.2009.110, indexed in Pubmed: 19327124.

17. Rashtchizadeh N, Ghaffari M, Sede SA, et al. Associations of pentraxin 3 with presence and severity of coronary artery disease in type 2 diabetes patients. Turk J Biochem. 2015; 40(1): 37-43, doi: 10.5505/ /tjb.2015.60024.

18. Jenny NS, Blumenthal RS, Kronmal RA, et al. Associations of pentraxin 3 with cardiovascular disease: the Multi-Ethnic Study of Atherosclerosis. J Thromb Haemost. 2014; 12(6): 999-1005, doi: 10.1111/ /jth.12557, indexed in Pubmed: 24628740.

19. Inoue K, Sugiyama A, Reid PC, et al. Establishment of a high sensitivity plasma assay for human pentraxin 3 as a marker for unstable angina pectoris. Arterioscler Thromb Vasc Biol. 2007; 27(1): 161-167, doi: 10.1161/01.ATV.0000252126.48375.d5, indexed in Pubmed: 17095712.

20. Dubin R, Li Y, IX JH, et al. Associations of pentraxin-3 with cardiovascular events, incident heart failure, and mortality among persons 
with coronary heart disease: data from the Heart and Soul Study. Am Heart J. 2012; 163(2): 274-279, doi: 10.1016/j.ahj.2011.11.007, indexed in Pubmed: 22305847.

21. Ogawa $\mathrm{T}$, Kawano $\mathrm{Y}$, Imamura $\mathrm{T}$, et al. Reciprocal contribution of pentraxin 3 and C-reactive protein to obesity and metabolic syndrome. Obesity (Silver Spring). 2010; 18(9): 1871-1874, doi: 10.1038/ /oby.2009.507, indexed in Pubmed: 20111016.

22. Barazzoni R, Aleksova A, Carriere C, et al. Obesity and high waist circumference are associated with low circulating pentraxin-3 in acute coronary syndrome. Cardiovasc Diabetol. 2013; 12: 167, doi: 10.1186/1475-2840-12-167, indexed in Pubmed: 24215445.

23. Tomandlova M, Jarkovsky J, Tomandl J, et al. Prognostic value of pentraxin-3 level in patients with STEMI and its relationship with heart failure and markers of oxidative stress. Dis Markers. 2015; 2015: 159051, doi: $10.1155 / 2015 / 159051$, indexed in Pubmed: 25922551.

24. Koga S, Ikeda S, Yoshida T, et al. Elevated levels of systemic pentraxin 3 are associated with thin-cap fibroatheroma in coronary culprit lesions: assessment by optical coherence tomography and intravascular ultrasound. JACC Cardiovasc Interv. 2013; 6(9): 945-954, doi: 10.1016/j.jcin.2013.04.024, indexed in Pubmed: 23954061.

25. Vuković-Dejanović V, Bogavac-Stanojević N, Spasić S, et al. Association of serum pentraxin-3 and high-sensitivity C-reactive protein with the extent of coronary stenosis in patients undergoing coronary angiography. J Med Biochem. 2015; 34(4): 440-449, doi: 10.2478/ /jomb-2014-0061.

26. Liu H, Guan S, Fang W, et al. Associations between pentraxin 3 and severity of coronary artery disease. BMJ Open. 2015; 5(4): e007123, doi: 10.1136/bmjopen-2014-007123, indexed in Pubmed: 25854969.

27. Klouche M, Peri G, Knabbe C, et al. Modified atherogenic lipoproteins induce expression of pentraxin-3 by human vascular smooth muscle cells. Atherosclerosis. 2004; 175(2): 221-228, doi: 10.1016/j.atherosclerosis.2004.03.020, indexed in Pubmed: 15262177.

28. Norata GD, Marchesi P, Pulakazhi Venu VK, et al. Deficiency of the long pentraxin PTX3 promotes vascular inflammation and atherosclerosis. Circulation. 2009; 120(8): 699-708, doi: 10.1161/CIRCULATIONAHA.108.806547, indexed in Pubmed: 19667236.

29. Camozzi M, Zacchigna S, Rusnati M, et al. Pentraxin 3 inhibits fibroblast growth factor 2-dependent activation of smooth muscle cells in vitro and neointima formation in vivo. Arterioscler Thromb Vasc Biol. 2005; 25(9): 1837-1842, doi: 10.1161/01.ATV.0000177807.54959.7d, indexed in Pubmed: 16020751.

30. Brambilla M, Camera M, Colnago D, et al. Tissue factor in patients with acute coronary syndromes: expression in platelets, leukocytes, and platelet-leukocyte aggregates. Arterioscler Thromb Vasc Biol. 2008;
28(5): 947-953, doi: 10.1161/ATVBAHA.107.161471, indexed in Pubmed: 18292391.

31. Santilli F, Guagnano MT, Innocenti P, et al. Pentraxin 3 and platelet activation in obese patients after gastric banding. Circ J. 2016; 80(2): 502-511, doi: 10.1253/circj.CJ-15-0721, indexed in Pubmed: 26632534.

32. Kume N, Mitsuoka H, Hayashida K, et al. Pentraxin 3 as a biomarker for acute coronary syndrome: comparison with biomarkers for cardiac damage. J Cardiol. 2011; 58(1): 38-45, doi: 10.1016/j. jjcc.2011.03.006, indexed in Pubmed: 21616640.

33. Latini R, Gullestad L, Masson S, et al. Investigators of the Controlled Rosuvastatin Multinational Trial in Heart Failure (CORONA) and GISSI-Heart Failure (GISSI-HF) trials. Pentraxin-3 in chronic heart failure: the CORONA and GISSI-HF trials. Eur J Heart Fail. 2012; 14(9): $992-$ -999, doi: 10.1093/eurjhf/hfs092, indexed in Pubmed: 22740508.

34. Kimura S, Inagaki H, Haraguchi Go, et al. Relationships of elevated systemic pentraxin-3 levels with high-risk coronary plaque components and impaired myocardial perfusion after percutaneous coronary intervention in patients with ST-elevation acute myocardial infarction. Circ J. 2014; 78(1): 159-169, indexed in Pubmed: 24132243.

35. Guo R, Li Y, Wen J, et al. Elevated plasma level of pentraxin-3 predicts in-hospital and 30-day clinical outcomes in patients with non-ST-segment elevation myocardial infarction who have undergone percutaneous coronary intervention. Cardiology. 2014; 129(3): 178-188, doi: 10.1159/000364996, indexed in Pubmed: 25323314.

36. Matsui S, Ishii J, Kitagawa F, et al. Pentraxin 3 in unstable angina and non-ST-segment elevation myocardial infarction. Atherosclerosis. 2010; 210(1): 220-225, doi: 10.1016/j.atherosclerosis.2009.10.033, indexed in Pubmed: 19945702.

37. Miyazaki T, Chiuve S, Sacks FM, et al. Plasma pentraxin 3 levels do not predict coronary events but reflect metabolic disorders in patients with coronary artery disease in the CARE trial. PLoS One. 2014; 9(4): e94073, doi: 10.1371/journal.pone.0094073, indexed in Pubmed: 24705587.

38. Suzuki S, Takeishi Y, Niizeki T, et al. Pentraxin 3, a new marker for vascular inflammation, predicts adverse clinical outcomes in patients with heart failure. Am Heart J. 2008; 155(1): 75-81, doi: 10.1016/j. ahj.2007.08.013, indexed in Pubmed: 18082493.

39. Saygı S, Kırılmaz B, Tengiz i, et al. Long pentraxin-3 measured at late phase associated with GRACE risk scores in patients with non-ST elevation acute coronary syndrome and coronary stenting. Turk Kardiyol Dern Ars. 2012; 40(3): 205-212, doi: 10.5543/tkda.2012.90083, indexed in Pubmed: 22864315.

40. Matsubara J, Sugiyama S, Nozaki T, et al. Incremental prognostic significance of the elevated levels of pentraxin 3 in patients with heart failure with normal left ventricular ejection fraction. J Am Heart Assoc. 2014; 3(4), doi: 10.1161/JAHA.114.000928, indexed in Pubmed: 2501228. 